\title{
The effect of platinum-rhodium active coating application in self-ignition engine on policyclic aromatic hydrocarbons concentration in exhausts
}

\begin{abstract}
Polycyclic aromatic hydrocarbons (PAHs) are known to be mutagenic and carcinogenic group of substances. One of the most important anthropogenic source of these hydrocarbons is motorization (especially diesel engines). The most effective method of PAHs removal from exhaust gasses is using catalytic converters in vehicle exhaust systems. This paper presents results of measurements of polycyclic aromatic hydrocarbons emissions from self-ignition engine with platinum-rhodium active coating application inside.
\end{abstract}

Key words: catalyst, polycyclic aromatic hydrocarbons, catalytic layers, self-ignition engine

\section{Wpływ zastosowania platynowo-rodowej powłoki aktywnej wewnątrz silnika o zapłonie samoczynnym na stężenie wielopierścieniowych weglowodorów aromatycznych w spalinach}

\begin{abstract}
Wielopierścieniowe węglowodory aromatyczne (WWA) należa do grupy związków uznanych za mutagenne i kancerogenne. Jednym z najważniejszych antropogenicznych źródet emisji tych związków jest motoryzacja a w szczególności, ze względu na specyfikę prowadzenia procesu spalania paliwa, silniki o zapłonie samoczynnym. Najskuteczniejsza metoda usuwania WWA ze spalin silnikowych jest ich katalityczne oczyszczanie. W niniejszym artykule przedstawiono wyniki badań, których celem była ocena wptywu zastosowania katalizatora we wnętrzu silnika o zapłonie samoczynnym na zawartość WWA w spalinach.
\end{abstract}

Słowa kluczowe: wewnętrzny katalizator spalania, wielopierścieniowe węglowodory aromatyczne, silnik o zapłonie samoczynnym

\section{Introduction}

Toxic substances emission from combustion engines is a significant global problem. Some polycyclic and volatile organic combinations very often determinate hazardous effect of engine exhaust gases on humans because of their mutagenic and carcinogenic properties. Their concentration in combustion engine exhaust is not directly limited. Numerous of toxicology and epidemiology researches [1-6] shows visible relations between human exposure to this substances and increase of cancer risk. Human organism cells are tiring to remove polycyclic aromatic hydrocarbons by connecting them with hydroxyl group. Some products of this process can be combine with nucleolus DNA, which causes damages of genetic material and various mutations.

In Poland Recommended Maximum Concentration Limit (RMCL) for benzo(a)pirene $-0.002 \mathrm{mg} / \mathrm{m}^{3}$ and dibenzo (a,h)antracene $-0.001 \mathrm{mg} / \mathrm{m}^{3}$ had been determinated as yet [7]. Special units for RMCL and RMIL (Recommended Maximum Intensity Limit) determination accepted RMCL as $0.002 \mathrm{mg} / \mathrm{m}^{3}$ as PAHs concentration sum augment to Relative Carcinogenic Coefficient according to Nisbet and LaGoy [4] (Tab. 1).

Problem of polycyclic aromatic hydrocarbons emission is important especially in case of diesel engines (self ignition engines) because of specific, unstable physical-chemical condition of fuel combustion process (local oxygen deficiency).

Limitation of unburned hydrocarbons emission required beside improvement of off-engine methods of exhausts

\section{Wstep}

Emisja substancji toksycznych z silników spalinowych jest ważnym problemem globalnym. Obecne w spalinach węglowodory, szczególnie z grupy połączeń wielopierścieniowych oraz lotnych, ze względu na swoje kancerogenne i mutagenne właściwości bardzo często determinują szkodliwy wpływ gazów spalinowych na organizmy żywe, pomimo że ich stężenie w spalinach nie jest bezpośrednio limitowane. Liczne badania toksykologiczne i epidemiologiczne [1-6] wskazują na zależność pomiędzy ekspozycją na te związki a wzrostem ryzyka powstawania nowotworów. Komórki organizmu próbują usuwać WWA przez przyłączanie do nich grup hydroksylowych, lecz niektóre powstające w ten sposób pochodne mogą wiązać się z DNA jądra komórkowego, co powoduje uszkodzenie materiału genetycznego i różnego rodzaju mutacje.

Dotychczas w kraju ustalono wartości normatywów higienicznych NDS (najwyższego dopuszczalnego stężenia) dla benzo(a)pirenu $-0,002 \mathrm{mg} / \mathrm{m}^{3}$ i dibenzo(a,h)antracenu $-0,001 \mathrm{mg} / \mathrm{m}^{3}$ [7]. W roku 1998 Międzyresortowa Komisja ds. NDS i NDN (najwyższego dopuszczalnego natężenia) zaakceptowała zaproponowaną przez Zespół Ekspertów ds. Czynników Chemicznych dla WWA wartość NDS $0,002 \mathrm{mg} / \mathrm{m}^{3}$ jako sumę stężeń WWA pomnożonych przez współczynniki kancerogenności określone przez Nisbeta i LaGoy'a (tab. 1) [4].

Problem emisji WWA, ze względu na specyfikę prowadzenia procesu spalania paliwa (m.in. występujące lokalnie niedobory tlenu) jest szczególnie istotny $\mathrm{w}$ odniesieniu 
Table 1. PAHs Relative Carcinogenic Coefficients determinated by Nisbet and LaGoy [4]

Tabela 1. Względne współczynniki kancerogenności określone dla WWA w pracy Nisbeta i LaGoy'a [4]

\begin{tabular}{|l|c|}
\hline \multicolumn{1}{|c|}{ PAHs/zwiazek } & RCC/WWK \\
\hline Benzo(a)pirene/benzo(a)piren & 1.00 \\
\hline Benzo(a)antracene/benzo(a)antracen & 0.10 \\
\hline Indeno(1,2,3-c,d)pirene/indeno(1,2,3-c,d)piren & 0.10 \\
\hline Antracene/antracen & 0.01 \\
\hline Chryzene/chryzen & 0.001 \\
\hline Naphtalene/naftalen & 0.001 \\
\hline Acenaphtylene/acenaftylen & 0.001 \\
\hline Acenaphtene/acenaften & 0.001 \\
\hline Fluorene/fluoren & 0.001 \\
\hline Phenantrene/fenantren & 0.001 \\
\hline Pirene/piren & 0.001 \\
\hline
\end{tabular}

gases purification also direct interference in combustion self-ignition engine.

\section{Experiment}

A VW 1.9 TDI self-ignition engine (diesel engine) was used as a research engine with engine modification consisted in application of platinum-rhodium catalyst on engine glow plugs (inner catalyst). Zirconium ceramic was used as a catalyst support layer and a local thermal barrier. A scheme of the inner catalyst is shown in the Fig. 1.

Conventional fuel (commercial diesel oil) was used as engine fuel. Two characteristic engine loads: idle run and $150 \mathrm{~N} \cdot \mathrm{m}$, were chosen. A scheme of research work stand engine test house - is presented in the Fig. 2. process. An example is inner catalyst application inside of

do silników o zapłonie samoczynnym. Ograniczenie toksycznych emisji z silników ZS oprócz doskonalenia pozasilnikowych metod oczyszczania spalin wymaga również bezpośredniej ingerencji w proces spalania. Taką ingerencję stanowi rozwiązanie polegające na zastosowaniu katalizatora wewnątrz przestrzeni spalania silnika.

\section{Eksperyment}

Do badań wykorzystano silnik VW 1,9 TDI o zapłonie samoczynnym. W przestrzeń spalania silnika wprowadzono platynowo-rodową warstwę aktywną umieszczoną na powierzchni żarników świec żarowych, zwaną dalej w pracy katalizatorem wewnętrznym. Warstwę aktywną naniesiono na cyrkonową powłokę ceramiczną umożliwiającą lepsze rozwinięcie powierzchni katalizatora oraz spełniającą rolę lokalnej bariery termicznej (rys. 1).

Silnik pracował bez obciążenia (na biegu jałowym) oraz $\mathrm{z}$ obciążeniem $150 \mathrm{~N} \cdot \mathrm{m}$. Przyjęte obciążenia zawarte są w zakresie obciążeń użytkowych. Prędkość obrotową dobrano w obszarze maksymalnego momentu obrotowego (2500 obr/min). Schemat stanowiska badawczego przedstawiono na rys. 2 .

Zestaw do poboru prób gazów spalinowych składał się z sorbentu (rurki z węglem aktywnym typu SKC-lot 120) oraz filtra z włókna szklanego (Staplex TF AGF 810). Pobór odbywał się dwustopniowo, ponieważ WWA w gazach spalinowych, ze względu na nieustabilizowane warunki charakteryzujące procesy spalania paliw w silnikach, występują w stanie wolnym w postaci par oraz w postaci zaadsorbowanej na porowatej powierzchni cząstek stałych. Ekstrakcja WWA zaadsorbowanych na węglu aktywnym odbywała się za pomocą chlorku metylenu w łaźni ultradźwiękowej. $\mathrm{W}$ celu oczyszczenia ekstraktu z substancji przeszkadzających za-

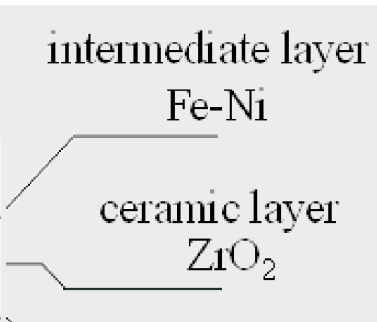

b)
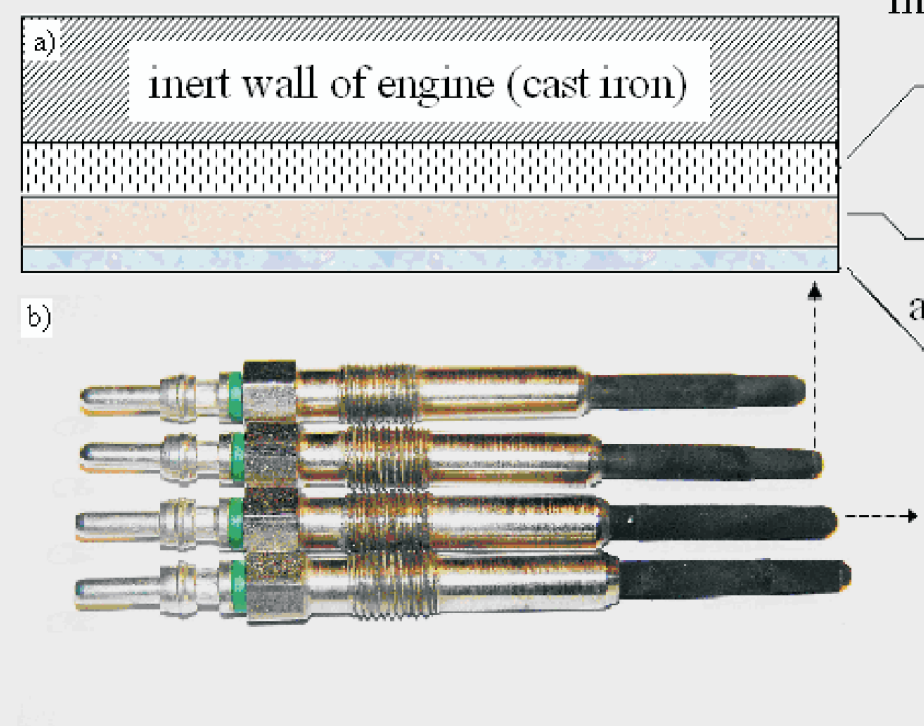

active layer ( $\mathrm{Pt} / \mathrm{Rh})$

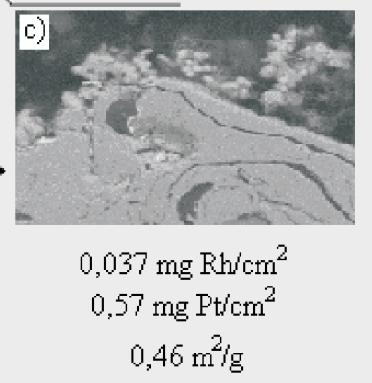

Fig. 1. Inner catalyst (active layers inside the engine): a) scheme of catalyst layers, b) engine glow plugs with platinum-rhodium active layer, c) view of inner catalyst from electron-scanning microscope (cross-section)

Rys. 1. Katalizator wewnętrzny (platynowo-rodowa powłoka aktywna we wnętrzu silnika): a) schemat budowy warstw wewnętrznego katalizatora spalania, b) świece żarowe silnika VW 1,9 TDI z warstwa aktywna, c) przekrój poprzeczny przez warstwę katalizatora - mikroskop elektronowo-skaningowy stosowano metodę SPE (Solid Phase Extraction) - technikę ekstrakcji do fazy stałej, którą zalecają współczesne przepisy analityczne. Czynnikiem ekstrahującym był szerokoporowaty żel krzemionkowy ze związanymi na jego powierzchni grupami alkilowymi o 18. atomach węgla w łańcuchu (C-18). Analizę chromatograficzną prowadzono na chromatografie gazowym Hewlett-Packard 5890, z detektorem płomieniowo-jonizacyjnym, umożliwiającym ilościowe i jakościowe oznaczanie zaadsorbowanych WWA. Chromatograf zawierał kolumnę kapilarną HP-5 
Analysis procedure of polycyclic aromatic hydrocarbons concentration in exhaust gases was consisted of few important stages: uptake stage, research material recovery, sample purification and enrichment, chromatography analysis. Analytic procedure of PAHs marking is shown on Fig. 3.

Because of unstable parameters of engine work (pressure and temperature jumps) PAHs samples was uptaken by tubes with active coal, type SKC-lot 120, (gas phase) and by Staplex TF AGF 810 filters (PAHs adsorbed on particle matter). According to new analytic recommendations Solid Phase Extraction (SPE) was used for samples purification and enrichment. Gas chromatograph Hewlett-Packard 5890 with FID detector and capillary column (HP-5, 30 $\mathrm{m}, 0.53 \mathrm{~mm}$ ) was used for quantity and quality analysis. Calibration of the chromatograph was made by attested mixture of 16 model samples (according to EPA, USA). The temperature was programmed in the range $333-553 \mathrm{~K}$ with $15 \mathrm{deg} / \mathrm{min}$ increase.

\section{Results and discussion}

In result of the research work, which aim was PAHs marking in exhaust VW 1.9 TDI engine, six from possible 16 hydrocarbons was detected: acenaphtylene, acenaphthene, fluorene, phenanthrene, fluoranthene and pirene.

When engine was idle running without inner catalyst on engine glow plugs fluoranthene has a majority PAHs sum share (54\%). When engine worked with load the biggest share in PAHs sum has phenathrene (51\%). Share of particular polycyclic aromatic hydrocarbons in their sum is shown on Fig. 4.

Whereas engine worked without load phenantrene $(28 \%)$, fluorine $(9 \%)$, acenaphtylene $(5 \%)$ and acenaphtene (4\%) was also detected.

When engine load rose up to $150 \mathrm{~N} \cdot \mathrm{m}$, beside phenantrene, acenaphten $(30 \%)$, fluorene $(9 \%)$, acenaphtylen and fluoranthen (both $5 \%$ ) was detected.

Active coating application inside the engine caused reduction of PAHs quantity (from 5 to 2 in
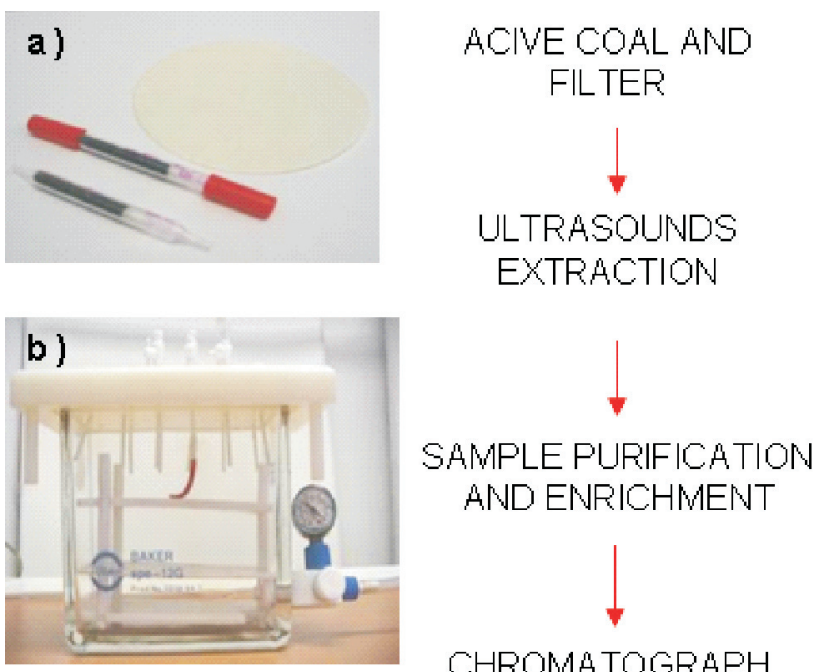

AWD ENRICHMENT
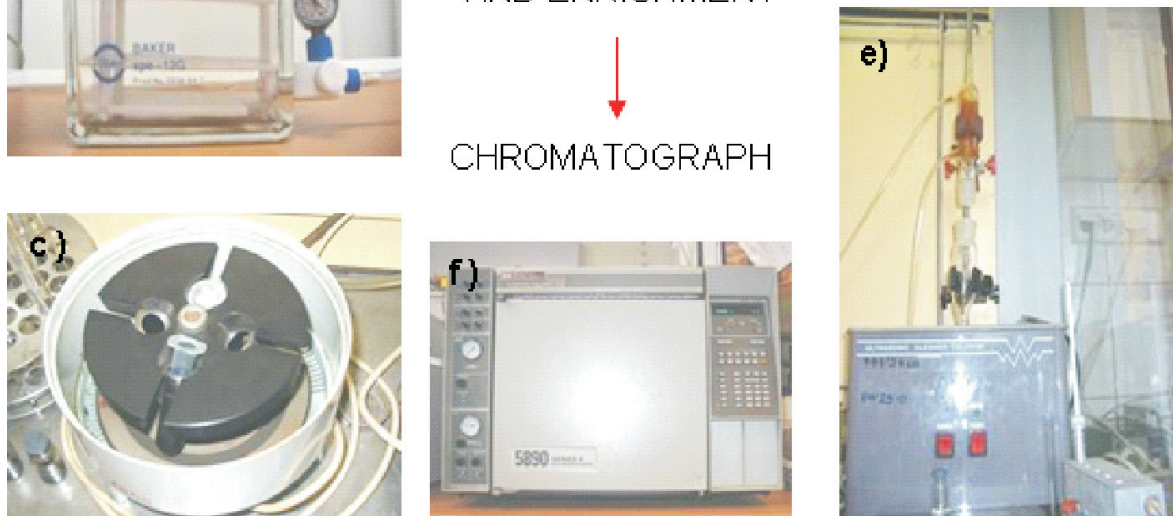

Fig. 3. The method of polycyclic aromatic hydrocarbons marking in engine exhaust : a) filter (Staplex TF AGF 810) and active coal tube (SKC-lot 120), b), c), d) the elements of SPE system, e) system of ultrasounds extraction, f) gas chromatograph HP 5890

Rys. 3. Metoda oznaczania WWA w gazach spalinowych: a) sączek z włókna szklanego (Staplex TF AGF 810) i rurka z węglem aktywnym (SKC-lot 120), b), c,) d) uktad SPE-ekstrakcja do fazy stałej, e) uktad do ekstrakcji WWA z próby za pomoca ultradźwięków, f) chromatograf gazowy HP 5890 
a)

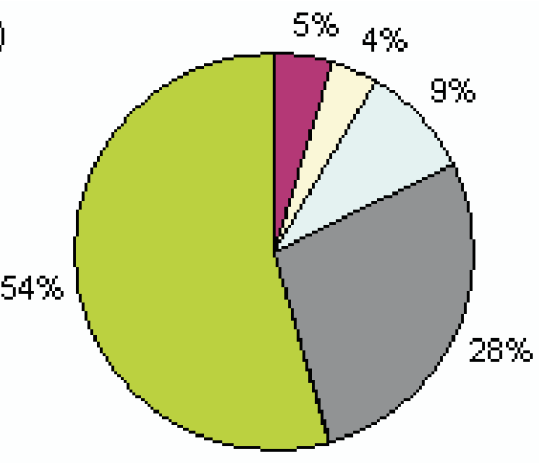

b)

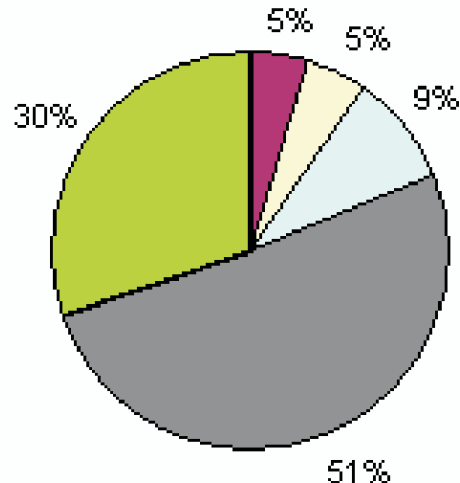

a Acenaphtylene a Acenaphtene a Fluorene a Phenantrene a Fluoranten

Fig. 4. Share of particular polycyclic aromatic hydrocarbons in their sum, VW 1.9 TDI engine without modification: a) idle run, b) engine load: $150 \mathrm{~N} \cdot \mathrm{m}$

Rys. 4. Udział poszczególnych związków w sumie WWA. Silnik VW 1,9TDI; fabryczna kompletacja silnika: a) praca silnika bez obciążenia, b) z obciążeniem $150 \mathrm{~N} \cdot \mathrm{m}$

case of idle run and from 5 to 3 whan engine worked with load).

When engine worked with catalyst, without any load, just two from 16 possible PAHs was detected (acenaphtylene $57 \%$ and fluoerene $43 \%$ ). Additionaly acenaphtylene was detected when engine worked with load $150 \mathrm{~N} \cdot \mathrm{m}$. Share of particular polycyclic aromatic hydrocarbons in their sum in this case amount accordingly for acenaphten, acenaphtylene and fluorene: $77 \%, 14 \%$ and $9 \%$ (Fig. 5).

To evaluate inner catalyst application effectivness on Fig. 6 and 7 quantity and quality of PAHs composition was commpared for both states of engine work (with and without catalyst). In case of both engine load (idle run and $150 \mathrm{~N} \cdot \mathrm{m}$ )
16 wzorców WWA zalecanej przez EPA (USA).

Metodę oznaczania WWA w gazach spalinowych przedstawiono na rys. 3 .

\section{Wyniki badań i ich dyskusja}

W wyniku przeprowadzenia analizy jakościowej spalin z silnika VW 1,9 TDI wykryto następujące związki spośród wielopierścieniowych węglowodorów aromatycznych: acenaftylen, acenaften, fluoren, fenantren, fluoranten oraz piren.

Podczas pracy silnika w stanie wyjściowym (bez zastosowania proponowanych zmian konstrukcyjnych) największy udział spośród zidentyfikowanych związków w przypadku a)

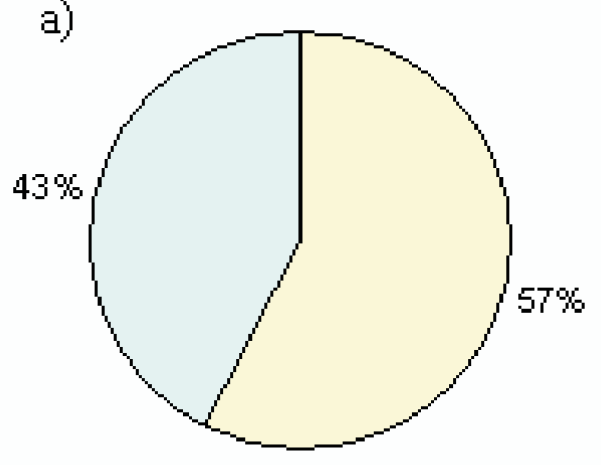

b)

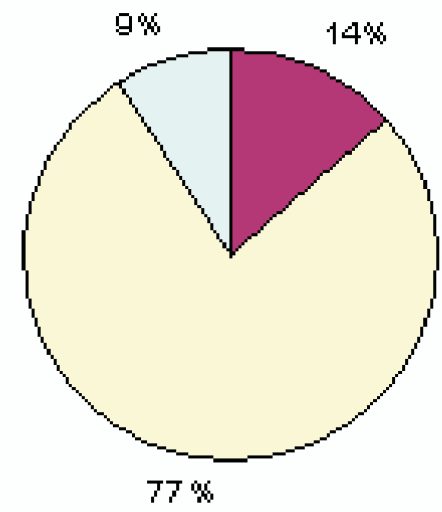

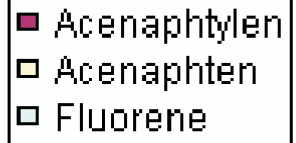

Fig. 5. Share of particular polycyclic aromatic hydrocarbons in their sum, VW 1.9 TDI engine with active layer on glow plugs: a) idle run, b) engine load: $150 \mathrm{~N} \cdot \mathrm{m}$

Rys. 5. Udział poszczególnych związków w sumie WWA. Silnik VW 1,9 TDI; świece żarowe z platynowo-rodową warstwą katalizatora: a) praca silnika bez obciążenia, b) z obciążeniem $150 \mathrm{~N} \cdot \mathrm{m}$

reduction of policyclic aromatic hydrocarbons concentration and their group share was observed (except acenaphten which concentration rise in both cases when engine worked with inner catalyst). biegu jałowego miał fluoranten (54\%), natomiast przy pracy silnika z obciążeniem $150 \mathrm{~N} \cdot \mathrm{m}$ - fenantren (51\%) (rys. 4).

Podczas pracy silnika na biegu jałowym wykryto ponadto fenantren (28\%), fluoren (9\%) acenaftylen (5\%) i acenaften (4\%). 


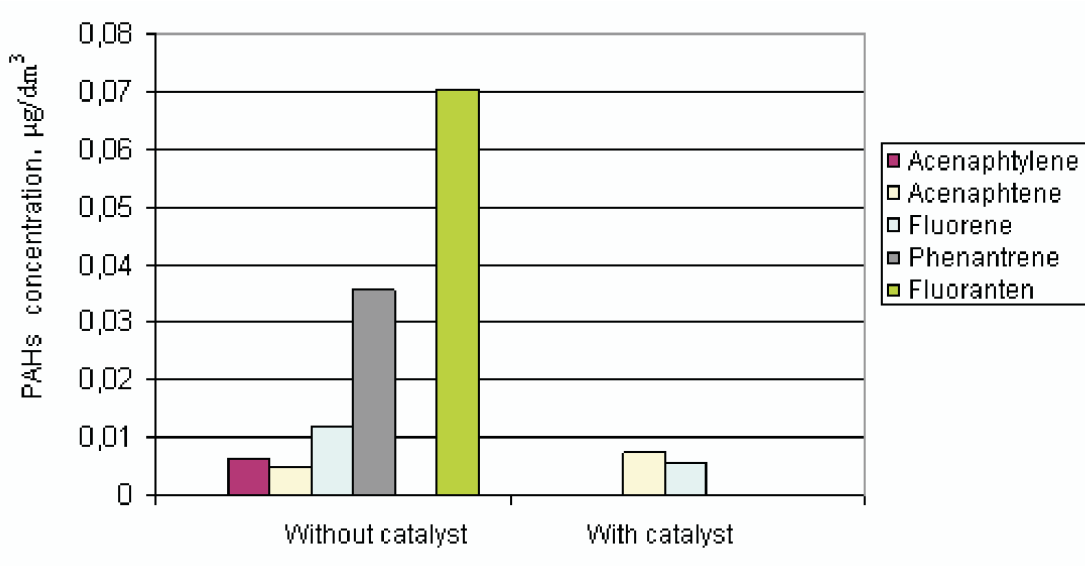

Fig. 6. Concentration of policyclic aromatic hydrocarbons in exhaust of VW 1.9 TDI engine with and without inner catalyst (idle run)

Rys. 6. Stężenie WWA zawartych w spalinach silnika VW 1,9 TDI pracujacego na biegu jałowym $w$ wariancie oryginalnym i po zastosowaniu warstwy platynowo-rodowej

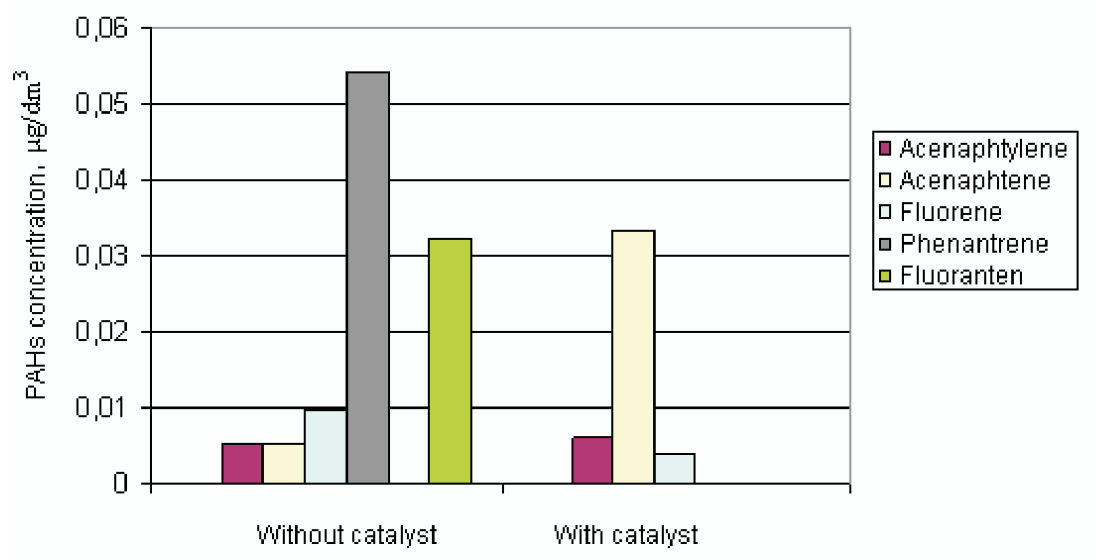

Fig. 7. Concentration of policyclic aromatic hydrocarbons in exhaust of VW 1.9 TDI engine with and without inner catalyst (engine load: $150 \mathrm{~N} \cdot \mathrm{m}$ )

Rys. 7. Stężenie WWA zawartych $w$ spalinach silnika VW 1,9 TDI pracującego z obciążeniem $150 \mathrm{~N} \cdot \mathrm{m} w$ wariancie oryginalnym i po zastosowaniu warstwy katalitycznej

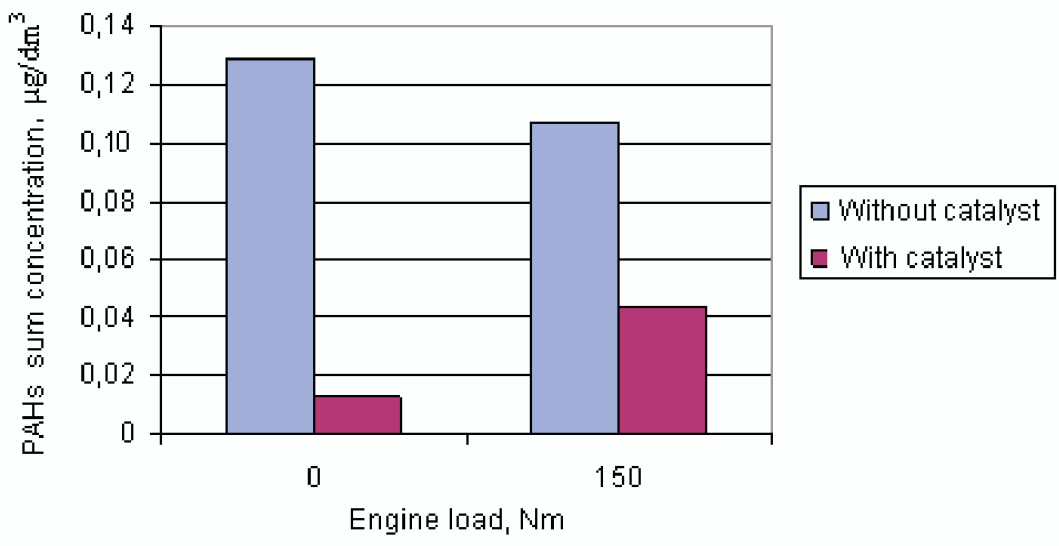

Fig. 8. Concentration of policyclic aromatic hydrocarbons sum in exhaust of VW 1.9 TDI engine with and without inner catalyst

Rys. 8. Suma stężeń WWA emitowanych podczas pracy silnika VW 1,9 TDI bez oraz $z$ zastosowaniem warstwy katalitycznej przy dwóch obciązeniach silnika
Gdy silnik pracował z zadanym obciążeniem, oprócz stanowiącego największy udział fluorantenu wykryto również acenaften (30\%), fluoren $(9 \%)$ oraz acenaftylen i fluoranten (po 5\%).

Zastosowanie powłoki katalitycznej platynowo-rodowej spowodowało znaczną redukcję ilości wytworzonych związków (z 5 do 2 przy biegu jałowym oraz z 5 do 3 z obciążeniem).

Gdy silnik pracował bez obciążenia wykryto jedynie dwa związki z grupy WWA (acenaftylen - 57\% i fluoren - 43\%), natomiast, gdy pracował z obciążeniem zidentyfikowano dodatkowo acenaften. Udziały poszczególnych związków w sumie WWA wyniosły dla acenaftenu, acenaftylenu i fluorenu odpowiednio $77 \%$, 14\% i 9\% (rys. 5).

W celu oceny wprowadzonych zmian konstrukcyjnych porównano analizę jakościową i ilościową dla obu stanów pracy silnika (stan wyjściowy i stan z katalizatorem) (rys. 6 i 7). Zarówno w przypadku biegu jałowego, jak i pracy z obciążeniem można zaobserwować redukcję ilości wykrytych związków oraz redukcję poziomu ich stężeń (za wyjątkiem acenaftenu, którego stężenie w obu przypadkach zwiększyło się po zastosowaniu katalizatora).

Porównując sumaryczne stężenie WWA dla obu stanów pracy silnika, można zauważyć, że zastosowanie wewnętrznego katalizatora spalin na świecach żarowych powoduje znaczną redukcję poziomu stężeń tych węglowodorów, szczególnie w sytuacji biegu jałowego (rys. 8).

Znaczące obniżenie stężenia sumy WWA w spalinach silnika $\mathrm{z}$ katalizatorem podczas jego pracy bez obciążenia jest szczególnie istotne ze względu na problem emisji niedopalonych węglowodorów. Podczas pracy silnika bez modyfikacji na biegu jałowym obserwuje się bowiem podwyższone stężenie węglowodorów w spalinach w stosunku do stężenia, gdy silnik pracuje z obciążeniem. Towarzyszy temu niska temperatura gazów spalinowych, kłopotliwe staje się więc również katalityczne dopalenie tych związków w tradycyjnych układach oczyszczania, gdzie do optymalnej skuteczności katalizator potrzebuje temperaturę większą niż $520 \mathrm{~K}$. 
In comparison of both states of engine work significant reduction of policyclic aromatic hydrocarbons sum concentration level in diesel exhaust in was observed (especially when engine was idle running) (Fig. 8).

Significant decrease of policyclic aromatic hydrocarbons sum concentration in diesel engine exhaust during its iddle run is particullary important because of problem of unburn hydrocarbons emission. When engine is idlle running higher emission of hydrocarbons is observed than when engine work with load. It is also conectled with lower temperature of exhaust gases. Traditional catalytic converters which are applied in vehicle exhaust systems to their optimal effectivness needs ehxhaust temperature higher than $520 \mathrm{~K}$.

\section{Conclusions}

1. The active factor application inside the VW 1.9 TDI engine (engine glow plugs with platinum-rhodium coating) had an significant impact od policyclic aromatic hydrocarbons concentration and their group share.

2. The inner catalyst application caused reduction of PAHs sum concentration in exhaust $(87 \%$ when engine was idlle running and $62 \%$ when engine worked with load $150 \mathrm{~N} \cdot \mathrm{m})$.

\section{Wnioski}

1. Wprowadzenie czynnika aktywnego w postaci katalitycznej warstwy platynowo-rodowej w przestrzeń spalania silnika VW 1,9 TDI wpłynęło znacząco na zawartość wielopierścieniowych węglowodorów aromatycznych w spalinach oraz ich skład grupowy.

2. Na skutek zastosowania katalizatora wewnętrznego $\mathrm{w}$ silniku, stężenie sumy WWA zmniejszyło się o prawie $87 \%$ podczas pracy silnika na biegu jałowym i o ponad $62 \%$ podczas pracy silnika z obciążeniem.

\section{Bibliography/Literatura}

[1] Czarny A., Zaczyńska E., Mendyka B., Janicka A.: Influence of biodiesel exhaust on NF-kB activation and TNF- $\alpha$ production in.human lung and peripheral blood leukocytes, in vitro. Materiały konferencyjne. IV Konferencja Naukowo-Szkoleniowa "Immunomodulacja: badania doświadczalne i kliniczne". Jurata, 25-26.05.2007.

[2] Environmental Protection Agency (EPA). Health Effects Assessment for polycyclic aromatic hydrocarbons (PAH). EPA 549/1-86-013. Environmental criteria and assessment office. Cincinnati, OH, 1984.

[3] Mendyka B., Radek P., Wargacka A., Czarny A., Zaczyńska E., Pawlik M.: Cytotoksyczność i mutagenność preparatów zawierających domieszkę estru metylowego oleju rzepakowego, Medycyna Środowiskowa 8 (2), 2005.
Artykut recenzowany

[4] Nisbet I.C.T., La Goy P.K.: Toxic equivalency factors (TEFs) for polycyclic aromatic hydrocarbons (PAHs). Reg. Toxicol. Pharmacol. 16, 290-300, 1992.

[5] Rhead M.M., Hardy S.A.: The sources of polycyclic aromatic compounds in diesel engine emission, Fuel 82 (2003), 385-393 .

[6] Sant-Georges F., Abbas I., Billet S., Verdin A., Gosset P., Mulliez P., Shirali P, Garcon G.: Gene expression induction of volatile organic compounds and/or polycyclic aromatic hydrocarbons - metabolizing enzymes in isolated human alveolar macrophages in response to airborne particulate matter (PM2,5). Toxicology 244, 2008, p. 220-230.

[7] Walkowiak W., Janicka A. i in.: Obniżanie toksyczności spalin silnika o zapłonie samoczynnym przez zastosowanie wewnętrznego katalizatora spalania. Raport Politechniki Wrocławskiej Seria: Spr. 47, 2007.
Ms. Anna Janicka, DEng. - assistant in the Faculty of Mechanical Engineering, Wroclaw University of Technology.

Dr inż. Anna Janicka - asystent na Wydziale Mechanicznym Politechniki Wrocławskiej. culty of Mechanical Engineering, Wroclaw University of Technology.

Dr inż. Wojciech Walkowiak - adiunkt na Wydziale Mechanicznym Politechniki Wrocławskiej.
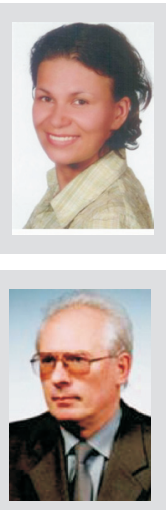

Prof. Włodzimierz Szczepaniak - Professor in the Faculty of Environmental Engineering, Wroclaw University of Technology.

Prof. dr hab. inż. Włodzimierz Szczepaniak-profesor nadzwyczajny na Wydziale Inżynierii Środowiska Politechniki Wrocławskiej. 